\title{
Impact of Workers' Remittances on Financial Development in Nigeria
}

\author{
Babatunde Olufemi Oke \\ Department of Finance, Faculty of Business Administration, \\ University of Lagos, Akoka, Lagos State, Nigeria \\ Tel: 234-803-444-2262Ｅ-mail: boke@unilag.edu.ng \\ Olayinka Marte Uadiale (Corresponding author) \\ Department of Accounting, Faculty of Business Administration, \\ University of Lagos, Akoka, Lagos State, Nigeria \\ Tel: 234-806-675-5555Ｅ-mail: ouadiale@unilag.edu.ng \\ Okwy Peter Okpala \\ Department of Accounting, Faculty of Business Administration, \\ University of Lagos, Akoka, Lagos State, Nigeria \\ Tel: 234-803-306-0763Ｅ-mail: okpalap@yahoo.com
}

Received: June 6, 2011 Accepted: June 15, 2011 doi:10.5539/ibr.v4n4p218

\begin{abstract}
In this study we examine the nexus between remittances and financial development (FINDEV) in Nigeria from 1977 to 2009. Towards achieving the objective of this study, we employ both the ordinary least square estimation (OLSE) technique and the Generalized Method of Moments (GMM) estimator. Moreover, key diagnostic tests are carried out in order to ascertain model adequacy. We also use two indicators of FINDEV, namely: the ratio of money supply to GDP $\left(\mathrm{m}_{2} / \mathrm{gdp}\right)$ and the ratio of private credit to GDP (cps/gdp). The results generally indicate that remittances positively and significantly influence financial development in Nigeria, with the exception of the cps/gdp measure of FINDEV in the GMM estimation where the coefficient is insignificant. This implies that remittances augment liquid liabilities more than loanable funds in Nigeria, as remittances are likely used more for consumption purposes than for productive ventures in the country. Since remittances provide foreign exchange that is vital to both the internal and the external sectors of the economy, they should be encouraged via appropriate policy formulation and implementation. Financial intermediaries and institutions operating in Nigerian should also intensify the mobilization of remittances with the aim of making them important sources of loanable funds in the country.
\end{abstract}

Keywords: Remittances, Financial development, Loanable funds, Financial intermediaries

\section{Introduction}

Remittances flowing into developing countries are attracting increasing attention because of their rising volume and their impact on recipient countries. Remittances are migrant workers' earnings sent back from the country of employment to the country of origin. They can also be referred to as financial resource flows arising from the cross border movement of nationals of a country (Kapur, 2003). Migrants' remittances have grown extraordinarily over the last twenty years. According to the World Bank (2011) inward remittances flows increased worldwide from US\$ 101.3 billion in 1995 to US\$ 274.9 billion in 2005 and to an estimated US\$ 440.1 billion in 2010. Correspondingly, inward remittances flows to developing countries grew from US\$ 55.2 billion in 1995 to US\$ 192.1 billion in 2005 and to an estimated US\$ 325.5 billion in 2010 (see table 1). Also, the share of developing countries in world's remittances inflow consistently rose from 54.49 percent in 1995 to 69.88 percent in 2005 and stood at 73.96 percent in 2010. The World Bank figures, presented in table 2 below, further show that workers' remittances are now the second largest source of external finance after foreign direct investment (FDI) and by 2009 it was almost thrice the official aid to developing countries. It is important to note that actual figures for workers' remittances will be considerably higher than captured by available data since a lot of funds are remitted through many informal channels.

Similarly, available data reveal that inward remittances flows to Sub-Saharan countries have been on the increase steadily. For instance, it grew by about 193.75 percent from US\$ 3.2 billion in 1995 to US\$ 9.4 billion in 2005 and by about 128.72 percent from the 2005 figure to the estimated US $\$ 21.5$ billion in 2010 . The top five recipients of remittances inflow in the region are Nigeria, with an estimated inflow of $\$ 10.0$ billion, followed by Sudan $(\$ 3.2$ billion), Kenya ( $\$ 1.8$ billion), Senegal ( $\$ 1.2$ billion), and South Africa ( $\$ 1.0$ billion), The flows to Sub-Saharan 
African countries have been considerably low over time. For instance, the region received a paltry 5.80 percent, 4.89 percent and 6.61 percent of the amount that went to developing countries in 1995, 2005 and 2010 respectively while the region's share of global inflow stood at 3.16 percent, 3.42 percent and 4.89 percent during the same corresponding periods (see table 3).

With respect to Nigeria, the steady rise in remittances inflow is also evident from available data presented in table 4 and charted in figure 2. Unlike the trend in foreign capital inflows to developing countries, however, remittances have consistently surpassed FDI since 2007. For instance, table 4 shows that while US\$6033 million worth of FDI was received by Nigeria in 2007, about US $\$ 9221$ was remitted to the country by Nigerians in the Diaspora the same year. Also, while FDI inflows have declined, with the 2008 and 2009 figures well below the amount recorded in 2007, remittances to the country have increased since 2007.

The foregoing has shown that remittances have been a major source of foreign capital inflows to developing countries, including Nigeria, over time. The pertinent question is: what are the contributions of remittances to financial development, economic growth and development, and poverty alleviation in developing countries over the years? Extant literature (such as Aggarwal, Demirgrüç-Kunt and Peria, 2006; Beck, and Demirgrüç-Kunt and Levine, 2007) have shown that remittances promote financial development as well as economic growth and development and at the same time play a key role in reducing poverty and inequality in developing countries. Unfortunately similar studies on Nigeria are virtually non-existence. To fill this lacuna, this study examines the impact of remittances on financial development in Nigeria.

The rest of the paper is structured as follows. The next section reviews the existing work on the impact of remittances on financial development. Section three provides a brief description of the data employed for the empirical analysis and specifies the estimation models. Section four presents the estimation results. The final section summarizes the findings and draws out some policy implications.

\section{Literature Review}

Most studies on remittances have focused on their impacts on economic growth, education, health, poverty, and entrepreneurial activity while that on financial development is scanty. Theoretically, the impact of remittances on financial development is vague. The perceived importance of remittances to the financial sector is underscored by the efforts of financial intermediaries to encourage remittance recipients to put remittances in the financial system (Orozco and Fedewa, 2005). It is believed that by so doing, the way will be paved for recipients to gain access to other financial products and services, from which they hitherto would be denied access. Also, since remittances are perceived to be huge and stable, banks could be encouraged to lend to the recipients and this could impact positively on credit market development and hence economic growth. Moreover, overall credit in the economy might increase if banks' loanable funds surge as a result of deposits linked to remittance flows. Indeed, remittances have been shown to alleviate the credit constraints faced by most people in developing countries (Funkhouser, 1992, and Woodruff and Zenteno, 2004).

Conversely, remittances may not increase loanable funds if they are consumed bank deposits may not increase if they are spent on consumption or if remittance recipients do not trust financial institutions enough to deposits their funds with them. Also, since remittances provide needed funds, recipients may have no need for credit from financial institutions and this will impact negatively on credit market development. Moreover, an increase in remittances may not necessarily increase credit to the private sector if banks prefer to hold liquid assets rather than lending or if they prefer to lend to the public sector instead of the private sector (Orozco and Fedewa, 2005, and Aggarwal, Demirguc-Kunt and Peria 2006).

Empirically, studies conducted so far on the impact of remittances on economic growth have yielded mixed results. For instance, Solimano (2003) finds a positive link between remittances and growth in Andean countries while Chami, Fullenkamp, and Jahjah (2003) show that a negative relationship exists between the two variables in a study of 113 countries over thirty year period. Indeed, their result confirm their model in which remittances lower the recipients' desire to work and this lack of drive in turn negatively affects productivity. IMF (2005), however, finds no correlation between remittances on economic growth.

Some studies show that financial development is an important link between remittances and economic growth. For instance, Giuliano and Ruiz-Arranz (2005) and Mundaca (2005) demonstrate that the effect of remittances on economic growth is dependent on the level of financial development in a country. Giuliano and Ruiz-Arranz (2005) study of 73 developing countries between 1975 and 2002 shows that remittances drive economic growth in less financially developed countries. They are of the opinion that in the absence of a well developed financial system, agents use remittances to provide the needed loanable funds for productive use, thereby promoting economic growth. Moreover, in analyzing the impact of workers' remittances on economic growth in Mexico, the Dominican Republic and in countries in Central America between 1970 and 2003, Mundaca (2005) show that financial development enhances the utilization of remittances, and consequently fostering economic growth. 
There are very little extant empirical studies on the role of remittances in financial development in the literature. One of such studies includes the one by Aggarwal, Demirguc-Kunt and Peria (2006) which examines this relationship in 99 developing countries between 1975 and 2003. They find that remittances has a positive impact on financial development in the recipient countries even after controlling for other factors affecting financial development and correcting for endogeneity biases that may emanate from omitted variables, reverse causation and measurement error. Similarly, Gupta, Pattillo and Wagh (2007), on their part investigate the impact of remittances on financial development in 44 Sub Saharan African (SSA) countries over six time periods, composed of five-year averages from 1975 to 2004 . Their findings confirm that remittances promote financial development in SSA, after controlling for other macroeconomic and institutional variables influencing financial development and correcting for reverse causality between remittances, poverty and financial development.

\section{Methodology}

\subsection{Model Specification}

To ascertain the relationship between remittances and financial development in Nigeria, we posit a bivariate model of the following form:

$$
\text { LOGFINDEV }=\sum_{j=1}^{n} \delta_{j}+\sum_{j=1}^{n} \Psi_{j}(\text { LOGREMY })+\varepsilon_{t}
$$

where:

LOGFINDEV is the log of financial development while LOGREMMY stands for the log of remittances, $\delta_{j}$ and $\Psi_{j}$ are the parameters to be estimated, and $\varepsilon_{t}$ is the error term. Financial development here refers to either the ratio of money supply (M2) to GDP (FINDEV) or the ratio of credit to the private sector to GDP (PRIVY).

Moreover, we determine the robustness of the independent partial correlation between remittances and financial development in Nigeria using the following model:

$$
\text { LOGFINDEV }=\sum_{j=1}^{n} \alpha_{j} X_{t}+\sum_{j=1}^{n} \beta_{j}(\text { LOGREMY })+\mu_{t}
$$

Where:

LOGFINDEV is the log of financial development; $\mathrm{X}$ is a set of control variables; $\alpha$ is a vector of coefficients on the variables in X; $\beta$ is the estimated coefficient of LOGREMY; and $\mu$ is an error term. We expect "a priori", $\beta>0$.

Finally, using GMM, we specify:

$$
\begin{aligned}
\text { LOGFINDEV }= & \phi_{j}+\lambda_{1}(\text { LOGREMY })+\lambda_{2}(L O G G D P)+\lambda_{3}(L O G O P E N)+\lambda_{4}(\text { LOGINF })+ \\
& \lambda_{5}(\text { EXRATE })+\lambda_{6}(\text { FINLIB })+\lambda_{7}(L O G R E M Y 1)+\varepsilon_{t}
\end{aligned}
$$

Where:

LOGFINDEV is the log of financial development, LOGREMY is the log of remittances, LOGGDP is the $\log$ of GDP, LOGOPEN is the log of the degree of openness, EXRATE is the dummy for dual exchange rates regimes, FINLIB is the dummy representing Financial Liberalization, LOGREMY1 is the log of one lag value of remittances, $\phi_{j}$ and $\lambda_{1}$ are the parameters to be estimated and $\varepsilon_{t}$ is the error term.

\subsection{Model Estimation Technique}

In this study, we employ time series econometric techniques to ascertain the nexus between remittances and financial development in Nigeria from 1977 to 2009. Specifically, we use ordinary least square estimation (OLSE) technique to establish the relationship and further carry out key diagnostic tests for the model to ascertain the adequacy of model 2 .

In addition to the above and to assuage the anxiety over reverse causality, we employ the Generalized Method of Moments (GMM) estimator which is a robust estimator to the extent that a lot of popular estimators in econometrics are regarded as special cases of GMM. The OLSE, for instance is regarded as a GMM estimator in which the independent variables are individually not correlated with the residual. For the GMM, we write the moment condition as an orthogonality condition between the parameters and a set of instrumental variables. To ensure that the GMM estimator is identified, we have the same number of instrumental variables as the parameters to be estimated. Thus, we use economic conditions such as foreign direct investment (FDI), financial liberalization, gross 
domestic product (GDP) and the lagged values of both remittances and financial development (remy1 and privy1) as instruments for the remittances flows received by Nigeria.

\subsection{Indicators of Remittances and Financial Development}

Two indicators of financial development are employed in this study. The first indicator, FINDEPTH is the ratio of money supply (M2) to GDP. Popularly referred to as financial depth, it measures the size of financial intermediaries as well as the level of financial intermediation. The second indicator is the ratio of credit to private sector to GDP (PRIVY). The rationale behind the choice of PRIVY is that financial systems that funnel more loanable funds to the private sector are more involved in performing the five functions of the financial system than financial systems that simply channel credit to the public sector. Moreover, Remittances (REMY) are current private transfers from migrant workers resident in the host country for more than a year, irrespective of their immigration status, to recipients in their country of origin. Migrants' transfers are defined as the net worth of migrants who are expected to remain in the host country for more than one year that is transferred from one country to another at the time of migration. Compensation of employees is the income of migrants who have lived in the host country for less than a year. All the data used in this study are in current U.S. dollars and were obtained from the World Bank Development Indicators 2010.

\subsection{Control Variables}

In equation 2 above, the matrix $X$ refers to a set of variables that extant literature has established as drivers of financial development. In this study we use country size (LOGGDP; the log of GDP in constant dollars), inflation rate (LOGINF; the log of annual percentage change in the GDP deflator), the degree of openness (LOGOPEN; the $\log$ of the ratio of trade to GDP), exchange rate (EXRATE; a dummy for the presence of dual exchange rates regimes), financial liberalization (FINLIB; a dummy that equals one in cases when there are no controls on domestic interest rates), and previous remittance (Logremy1; the log of the one lag value of remittances). For instance, Boyd, Levine, and Smith, (2001), Zoli (2007) and Bittencourt (2008), present empirical proof that inflation influences FINDEV while Dehesa, Druck, and Plekhanov (2007) show the effect of exchange rate on the ratio of credit to the private sector to GDP. Also, Chinn and Ito (2002) establish that trade openness drives FINDEV even as Demirguc-Kunt and Detragiache (1998) show that financial liberalization promotes FINDEV. Moreover, many studies (including Aggarwal, Demirgüç-Kunt, and Peria, 2006) confirm the impact of GDP on FINDEV while preliminary study shows that the log of one lag value of remittances (Logremy1) affects FINDEV in Nigeria.

\section{Research Findings}

The graphical presentation of an indicator of financial development (the ratio of credit to the private sector to GDP) and worker's remittances to Nigeria are presented in figures 3 and 4 below. The figures show that both variables trended upwards with varying degrees of fluctuations.

Moreover, in Table 5 below, we present the results of the relationship between remittances and financial development in Nigeria as modeled in equation 2 above. The regression results indicate that the coefficients of the indicators of remittances are both correctly signed and are significant at 5 percent level. This means that whether we measure financial development as the ratio of money supply to GDP (FINDEPTH) or ratio of credits to GDP (PRIVY), remittances positively and significantly influence financial development in Nigeria. The results further show that that an increase in remittances by one percentage point enhances financial development by 0.09 and 0.10 ., when we measure the latter as the ratio of money supply to GDP and as the ratio of credits to GDP respectively. This thus indicates that remittances not only boost the size of financial intermediaries and the level of financial intermediation, it also help funnel more loanable funds to the private sector in Nigeria during the period under consideration.

The results also indicate that although financial development is positively influenced by financial liberalization, previous year's remittances and the degree of openness, it is only the latter that exerts a significant effect when we use the ratio of credits to GDP as the indicator of financial development. Also, in line with our 'a priori' expectations, the results reveal that both inflation and exchange rate regimes exert negative effects on financial development, but the effect of the latter is more pronounced on financial development. The surprising result however is that, although the size of the economy is a significant predictor of financial development in Nigeria, it enters with the wrong sign regardless of the measure of financial development employed.

Table 6 presents the results of relevant diagnostic tests for the model. The results in general are satisfactory. The Breusch-Godfrey Serial Correlation LM Test shows that there is no evidence of autocorrelation while the Jaraue Bera test for residual indicates that the normality assumption is not violated. Also, the Harvey, White and Glejser tests establish that there is absence of heteroskedasticity while the ARCH LM test confirms the absence of ARCH effect in the residuals. The latter ensures that there is no loss of efficiency. Moreover the Ramsey Reset test shows that the model is well specified and that valid inferences can be made from the results of this study. 
In Table 7, we present the results of the relationship between remittances and financial development in Nigeria as specified in model 3 using the GMM approach. We establish that when we employ the ratio of money supply to GDP as our indicator of financial development, the coefficient of the indicator of remittances is correctly signed and is significant at 5 percent level. This means that remittances exert a positive influence on financial development in Nigeria and it confirms the results presented in table 5 above when we use the OLSE technique. On the other hand, when we employ the ratio of private credit to GDP (cps/gdp) as the indicator of financial development, the result shows that remittances insignificantly but positively influence financial development at 5 percent level. The implication of these results is that remittances augment liquid liabilities more than loanable funds in Nigeria as they are used more for consumption purposes than for productive ventures.

Consistent with the OLSE results above, Table 7 also reveals that financial liberalization, previous year's remittances and the degree of openness are positive predictors of financial development in Nigeria while inflation, exchange rate regimes and surprisingly, the size of the economy exert negative impacts on financial development in the country. Out of the six control variables, both the exchange rate regimes and the size of the economy are significant drivers of financial development (when we use the ratio of money supply to GDP) while only the size of the economy is significant predictors of financial development (when we use the ratio of credits to GDP).

\section{Conclusion and Recommendations}

In this study we examine the nexus between remittances and financial development (FINDEV) in Nigeria for the period 1977 to 2009. Towards achieving the objective of this study, we employ both the ordinary least square estimation (OLSE) technique as well as the Generalized Method of Moments (GMM) estimator. Moreover, key diagnostic tests are carried out in order to ascertain model adequacy. We also use two indicators of FINDEV, namely: the ratio of money supply to GDP $\left(\mathrm{m}_{2} / \mathrm{gdp}\right)$ and the ratio of private credit to GDP (cps/gdp). The results generally indicate that remittances positively and significantly influence financial development in Nigeria, with the exception of the cps/gdp measure of FINDEV in the GMM estimation where the coefficient is insignificant. The implication of this is that remittances augment liquid liabilities more than loanable funds in Nigeria, as remittances are likely used more for consumption purposes than for productive ventures in the country. Further results show that although financial development is positively influenced by financial liberalization, previous year's remittances and the degree of openness, both inflation and exchange rate regimes exert negative effects on financial development in Nigeria. Since remittances provide foreign exchange that is so vital to both the internal and the external sectors of the economy, they should be encouraged via appropriate policy formulation and implementation. Financial intermediaries and institutions operating in Nigerian should also intensify the mobilization of remittances with the aim of making them important sources of loanable funds in the country.

\section{References}

Aggarwal, Reena, Demirguc-Kunt, Asli and Peria, Maria Soledad Martinez. (2006). Do workers' Remittances Promote Financial Development? World Bank Policy Research Working Paper Series, WBPR WP No 3957, The World Bank, http://econpapers.repec.org/RePEc:wbk:wbrwps:3957.

Beck, T., Demirgüç-Kunt, A. and Levine, R. (2007). Finance, Inequality and the Poor', Journal of Economic Growth, Vol. 12, Number 1, pp.27-49, http://dx.doi.org/10.1007/s10887-007-9010-6

Bittencourt, M. (2011). Inflation and Financial Development : Evidence from Brazil, Economic Modelling, Vol. 28, No. 1-2, pp. 91-99., DOI:10.1016/j.econmod.2010.09.021

Boyd, J H, R. Levine, and Bruce D. Smith. (2001). The Impact of Inflation on Financial Sector Performance, Journal of Monetary Economics, Volume 47, Issue 2, pp 221-248, http://dx.doi.org/10.1016/S0304-3932(01)00049-6

Demirgrüç-Kunt, Asli and Enrica Detragiache. (1998). Financial Liberalization and Financial Fragility. International Monetary Fund Working Paper 9883. DOI: 10.1016/S0304-3932(01)00049-6

Chami, R., Fullenkamp, C. and Jahjah, S. (2003). Are Immigrant Remittance Flows a Source of Capital for Development? IMF Working Paper, No 03/189, http://EconPapers.repec.org/RePEc:imf:imfwpa:03/189

Chinn, Menzie David and Ito, Hiro. (2002). Capital Account Liberalization, Institutions and Financial Development: Cross Country Evidence, UC Santa Cruz Center for International Economics Working Paper No. 02-11. Available at SSRN: http://ssrn.com/abstract=315865 or doi:10.2139/ssrn.315865.

Dehesa, Mario, Druck, Pablo and Plekhanov, Alexander. (2007). Relative Price Stability, Creditor Rights, and Financial Deepening, IMF Working Papers, WP/07/139, Available at SSRN: http://ssrn.com/abstract=1007888.

Funkhouser, E. (1992). Migration from Nicaragua: Some Recent Evidence, World- Development, Vol. 20, Issue 8, pp. 1209-1218, http://dx.doi.org/10.1016/0305-750X(92)90011-J 
Giuliano, Paola and Marta Ruiz-Arranz. (2005). Remittances, Financial Development and Growth. Journal of Development Economics, Vol 90, Issue 1, Sept, pp 144-152. http://dx.doi.org/10.1016/j.jdeveco.2008.10.005

Gupta, S., Pattillo, C. A. and Wagh, S. (2007). Impact of Remittances on Poverty and Financial Development in Sub-Saharan Africa, IMF Working Paper WP/07/38, http://www.imf.org/external/pubs/ft/wp/2007/wp0738.pdf
IMF,
2005.
World
Economic
Outlook,
Washington,
D.C.,

http://www.imf.org/external/pubs/ft/weo/2005/01/index.htm

Mundaca, Gabriela B. (2005). Can Remittances Enhance Economic Growth? The Role of Financial Markets Development. http://www.sais-jhu.edu/bin/o/c/growth_remittances.pdf

Solimano, Andrés. (2003). Workers Remittances to the Andean Region: Mechanisms, Costs and Development Impact, http://www.remesasydesarrollo.org/uploads/media/workers_remittances_andean_region.pdf

Woodruff, C., and R. Zenteno. (2004). Remittances and Microenterprises in Mexico, IR/PS Working Paper, http://dornsife.usc.edu/IEPR/Events/Papers/Christopher_Woodruff.pdf

World Bank. (2011). Migration and Remittances Factbook, The International Bank for Reconstruction and Development / The World Bank, 2nd Edition, http://siteresources.worldbank.org/INTLAC/Resources/Factbook2011-Ebook.pdf

Zoli, Edda. (2007). Financial Development in Emerging Europe: The Unfinished Agenda. IMF Working Papers,

Vol. pp. 1-36. Available at SSRN: http://ssrn.com/abstract=1030687

Table 1.Global Remittances

\begin{tabular}{|l|l|l|l|l|l|l|l|l|l|}
\hline US\$ billions & $\mathbf{1 9 9 5}$ & $\mathbf{2 0 0 0}$ & $\mathbf{2 0 0 4}$ & $\mathbf{2 0 0 5}$ & $\mathbf{2 0 0 6}$ & $\mathbf{2 0 0 7}$ & $\mathbf{2 0 0 8}$ & $\mathbf{2 0 0 9}$ & $\mathbf{2 0 1 0 e}$ \\
\hline Inward remittance flows & $\mathbf{1 0 1 . 3}$ & $\mathbf{1 3 1 . 5}$ & $\mathbf{2 3 7 . 0}$ & $\mathbf{2 7 4 . 9}$ & $\mathbf{3 1 7 . 9}$ & $\mathbf{3 8 5 . 0}$ & $\mathbf{4 4 3 . 2}$ & $\mathbf{4 1 6 . 0}$ & $\mathbf{4 4 0 . 1}$ \\
\hline All developing countries & 55.2 & 81.3 & 159.3 & 192.1 & 226.7 & 278.5 & 324.8 & 307.1 & 325.5 \\
\hline Outward remittance flows & $\mathbf{9 7 . 5}$ & $\mathbf{1 0 8 . 5}$ & $\mathbf{1 6 8 . 0}$ & $\mathbf{1 8 5 . 3}$ & $\mathbf{2 1 3 . 7}$ & $\mathbf{2 5 5 . 2}$ & $\mathbf{2 9 5 . 7}$ & $\mathbf{2 8 2 . 5}$ & \\
\hline All developing countries & 10.4 & 9.5 & 28.5 & 33.0 & 41.0 & 52.7 & 67.3 & 58.7 & \\
\hline
\end{tabular}

Sources: World Bank (2011) "Migration and Remittances Factbook 2011” The International Bank for Reconstruction and Development / The World Bank, 2nd Edition Note: $2010 \mathrm{e}=2010$ estimate.

Table 2. Resource Flows to Developing Countries US\$ billions

\begin{tabular}{|l|l|l|l|l|l|l|l|l|l|}
\hline & $\mathbf{1 9 9 5}$ & $\mathbf{2 0 0 0}$ & $\mathbf{2 0 0 4}$ & $\mathbf{2 0 0 5}$ & $\mathbf{2 0 0 6}$ & $\mathbf{2 0 0 7}$ & $\mathbf{2 0 0 8}$ & $\mathbf{2 0 0 9}$ & $\mathbf{2 0 1 0}$ \\
\hline FDI & 95 & 149 & 208 & 276 & 346 & 514 & 593 & 359 & \\
\hline Remittances & 55 & 81 & 159 & 192 & 227 & 278 & 325 & 307 & 325 \\
\hline ODA & 57 & 49 & 79 & 108 & 106 & 107 & 128 & 120 & \\
\hline Private Debt and Portfolio Equity & 83 & 27 & 93 & 165 & 211 & 434 & 157 & 85 & \\
\hline
\end{tabular}

Sources: World Bank (2011) "Migration and Remittances Factbook 2011" The International Bank for Reconstruction and Development / The World Bank, 2nd Edition Note: Private debt includes only medium- and long-term debt. FDI is foreign direct investment; ODA is official development assistance; $-=$ not available.

Table 3. Remittances to Sub-Saharan Africa

\begin{tabular}{|l|l|l|l|l|l|l|l|l|l|}
\hline US\$ billions & $\mathbf{1 9 9 5}$ & $\mathbf{2 0 0 0}$ & $\mathbf{2 0 0 4}$ & $\mathbf{2 0 0 5}$ & $\mathbf{2 0 0 6}$ & $\mathbf{2 0 0 7}$ & $\mathbf{2 0 0 8}$ & $\mathbf{2 0 0 9}$ & $\mathbf{2 0 1 0 e}$ \\
\hline Inward remittance flows & 3.2 & 4.6 & 8.0 & 9.4 & 12.7 & 18.6 & 21.4 & 20.6 & 21.5 \\
\hline All developing countries & 55.2 & 81.3 & 159.3 & 192.1 & 226.7 & 278.5 & 324.8 & 307.1 & 325.5 \\
\hline World & $\mathbf{1 0 1 . 3}$ & $\mathbf{1 3 1 . 5}$ & $\mathbf{2 3 7 . 0}$ & $\mathbf{2 7 4 . 9}$ & $\mathbf{3 1 7 . 9}$ & $\mathbf{3 8 5 . 0}$ & $\mathbf{4 4 3 . 2}$ & $\mathbf{4 1 6 . 0}$ & $\mathbf{4 4 0 . 1}$ \\
\hline Outward remittance flows & 2.0 & 2.5 & 2.9 & 3.2 & 3.4 & 4.0 & 4.0 & 3.3 & - \\
\hline All developing countries & 10.4 & 9.5 & 28.5 & 33.0 & 41.0 & 52.7 & 67.3 & 58.7 & - \\
\hline World & 97.5 & 108.5 & $\mathbf{1 6 8 . 0}$ & $\mathbf{1 8 5 . 3}$ & $\mathbf{2 1 3 . 7}$ & $\mathbf{2 5 5 . 2}$ & $\mathbf{2 9 5 . 7}$ & $\mathbf{2 8 2 . 5}$ & \\
\hline
\end{tabular}

Sources: World Bank (2011) "Migration and Remittances Factbook 2011" The International Bank for Reconstruction and Development / The World Bank, 2nd Edition Note: $2010 \mathrm{e}=2010$ estimate.

Table 4. Resource Flows to Nigeria US\$ millions

\begin{tabular}{|l|l|l|l|l|l|l|l|l|}
\hline & $\mathbf{1 9 9 5}$ & $\mathbf{2 0 0 0}$ & $\mathbf{2 0 0 4}$ & $\mathbf{2 0 0 5}$ & $\mathbf{2 0 0 6}$ & $\mathbf{2 0 0 7}$ & $\mathbf{2 0 0 8}$ & $\mathbf{2 0 0 9}$ \\
\hline FDI & 1079.27 & 1140.14 & 1874.03 & 4982.53 & 8824.80 & 6033.00 & 4876.45 & 5786.68 \\
\hline Remittances & 804.00 & 1391.80 & 2272.70 & 3328.70 & 5435.00 & 9221.00 & 9980.00 & 9584.75 \\
\hline
\end{tabular}

Sources: World Bank (2011) "Migration and Remittances Factbook 2011" The International Bank for Reconstruction and Development / The World Bank, 2nd Edition 
Table 5. Impact of Remittances on Financial Development in Nigeria (OLSE)

\begin{tabular}{|c|c|c|}
\hline \multicolumn{3}{|c|}{ Dependent Variable: LOGFINDEV } \\
\hline Variables & $\begin{array}{c}\text { LOGPRIVY } \\
\text { (DC/GDP) }\end{array}$ & $\begin{array}{c}\text { LOGFINDEPTH } \\
\text { (M2/GDP) }\end{array}$ \\
\hline LOGREMY & $\begin{array}{c}0.103801^{* *} \\
(2.349344) \\
\{0.0298\} \\
\end{array}$ & $\begin{array}{c}0.091115^{* *} \\
(2.472149) \\
\{0.0231\} \\
\end{array}$ \\
\hline LOGGDP & $\begin{array}{c}-1.651921 * * * \\
(-3.535899) \\
\{0.0022\}\end{array}$ & $\begin{array}{c}-1.354713^{* * *} \\
(-3.476141) \\
\{0.0025\}\end{array}$ \\
\hline LOGOPEN & $\begin{array}{c}0.722879 * * \\
(2.253526) \\
\{0.0362\}\end{array}$ & $\begin{array}{c}0.235022 \\
(0.878304) \\
\{0.3908\} \\
\end{array}$ \\
\hline LOGINF & $\begin{array}{c}-0.035993 \\
(-0.983213) \\
\{0.3379\} \\
\end{array}$ & $\begin{array}{c}-0.022504 \\
(-0.736921) \\
\{0.4702\} \\
\end{array}$ \\
\hline EXRATE & $\begin{array}{c}-0.549676^{* * *} \\
(-4.522821) \\
\{0.0002\}\end{array}$ & $\begin{array}{c}-0.465170 * * * \\
(-4.588316) \\
\{0.0002\}\end{array}$ \\
\hline FINLIB & $\begin{array}{c}0.328269^{*} \\
(1.952583) \\
\{0.0658\} \\
\end{array}$ & $\begin{array}{c}0.103348 \\
(0.736918) \\
\{0.4702\} \\
\end{array}$ \\
\hline LOGREMY1 & $\begin{array}{c}0.067929 \\
(1.551692) \\
\{0.1372\} \\
\end{array}$ & $\begin{array}{c}0.000218 \\
(0.005969) \\
\{0.9953\} \\
\end{array}$ \\
\hline Constant & $\begin{array}{c}36.74938^{* * *} \\
(3.565998) \\
\{0.0021\}\end{array}$ & $\begin{array}{l}33.46682 * * * \\
(3.893004) \\
\{0.0010\}\end{array}$ \\
\hline Observations & 33 & 33 \\
\hline R-squared & 0.614742 & 0.805548 \\
\hline Adjusted R-squared & 0.472804 & 0.733908 \\
\hline Akaike info criterion & -0.634287 & -0.996895 \\
\hline Schwarz criterion & -0.250335 & -0.612943 \\
\hline F-statistic & 4.331078 & 11.24439 \\
\hline Prob (F-statistic) & 0.005080 & 0.000014 \\
\hline
\end{tabular}

Note: $* * *$, and $* * *$ denote significance at the 10,5 , and 1 percent level, respectively.

Figures in brackets are the $t$ statistics while the ones in parentheses are the p-values

Source: Authors' computation

Table 6. Summary of Diagnostic Tests for the Model

\begin{tabular}{|l|c|c|}
\hline Diagnostic Tests & $\begin{array}{c}\text { LOGPRIVY } \\
\text { (DC/GDP) }\end{array}$ & $\begin{array}{c}\text { LOGFINDEPTH } \\
\text { (M2/GDP) }\end{array}$ \\
\hline Breusch-Godfrey Serial Correlation LM Test: & 2.186578 & 1.161838 \\
& $(0.1429)$ & $0.336553)$ \\
\hline ARCH LM Test & 0.311240 & 0.179998 \\
& $(0.5826)$ & $(0.675495)$ \\
\hline White Heteroskedasticity Test: (No Cross Terms) & 0.497911 & 0.019677 \\
& $(0.8835)$ & $(0.480547)$ \\
\hline Harvey Heteroskedasticity Test: & 1.079025 & 0.989794 \\
& $(0.4141)$ & $(0.4676)$ \\
\hline Glejser Heteroskedasticity Test: & 0.923860 & 0.468429 \\
& $(0.4440)$ & $(0.8453)$ \\
\hline Jarque-Bera Normality Tests & 1.526326 & 1.686060 \\
& $(0.4662)$ & $(0.430404)$ \\
\hline Ramsey RESET Test: & 0.000000818 & $(0.9993)$ \\
\end{tabular}

Note: Figures are the F statistics and the probabilities (in brackets)

Source: Authors' computation. 
Table 7. Impact of Remittances on Financial Development in Nigeria (GMM)

\begin{tabular}{|c|c|c|}
\hline Variables & $\begin{array}{l}\text { LOGPRIVY } \\
\text { (DC/GDP) }\end{array}$ & $\begin{array}{l}\text { LOGFINDEPTH } \\
\text { (M2/GDP) }\end{array}$ \\
\hline LOGREMY & $\begin{array}{c}0.208247 \\
(1.439308) \\
\{0.1672\} \\
\end{array}$ & $\begin{array}{c}0.135156 \\
(2.122092) \\
\{0.0480\}^{* *} \\
\end{array}$ \\
\hline LOGGDP & $\begin{array}{c}-2.818254 \\
(-2.972879) \\
\{0.0082\} * * *\end{array}$ & $\begin{array}{c}-2.093157 \\
(-4.273844) \\
\{0.0005\} * * *\end{array}$ \\
\hline LOGOPEN & $\begin{array}{c}1.788384 \\
(0.307543) \\
\{0.7620\}\end{array}$ & $\begin{array}{c}1.375096 \\
(0.745757) \\
\{0.4654\}\end{array}$ \\
\hline LOGINF & $\begin{array}{c}-0.031269 \\
(-0.350108) \\
\{0.7303\} \\
\end{array}$ & $\begin{array}{c}-0.024327 \\
(-0.942187) \\
\{0.3586\} \\
\end{array}$ \\
\hline EXRATE & $\begin{array}{c}-0.962555 \\
(-0.815703) \\
\{0.4253\}\end{array}$ & $\begin{array}{l}-0.625735 \\
(-2.122058) \\
\{0.0480\} * *\end{array}$ \\
\hline FINLIB & $\begin{array}{c}0.937968 \\
(0.747013) \\
\{0.4647\}\end{array}$ & $\begin{array}{c}0.610354 \\
(1.204520) \\
\{0.2440\} \\
\end{array}$ \\
\hline LOGREMY1 & $\begin{array}{c}0.072738 \\
(0.040069) \\
\{0.0862\}^{*} \\
\end{array}$ & $\begin{array}{c}0.016904 \\
(0.330620) \\
\{0.7447\} \\
\end{array}$ \\
\hline Constant & $\begin{array}{c}58.74979 \\
(1.413142) \\
\{0.1747\}\end{array}$ & $\begin{array}{l}45.67990 \\
(3.547658) \\
\{0.0023\}^{* * *}\end{array}$ \\
\hline Observations & 33 & 33 \\
\hline R-squared & 0.193188 & 0.607755 \\
\hline Adjusted R-squared & -0.120572 & 0.455215 \\
\hline
\end{tabular}

Note: ${ }^{*}, *$, and $* * *$ denote significance at the 10,5 , and 1 percent level, respectively.

Figures in brackets are the $t$ statistics while the ones in parentheses are the p-values

Source: Authors' computation

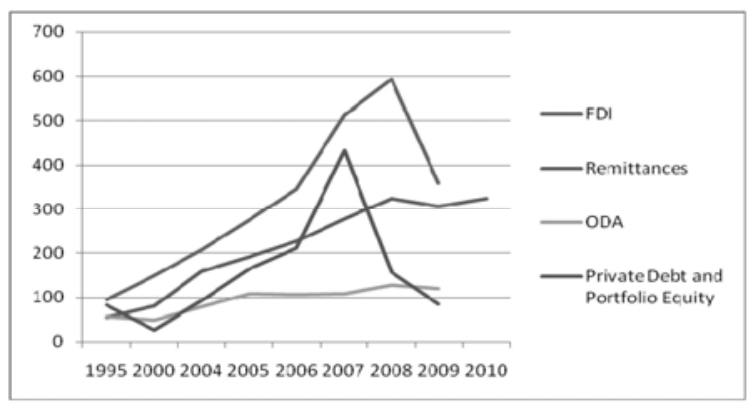

Figure 1. Resource Flows to Developing Countries US\$ billions

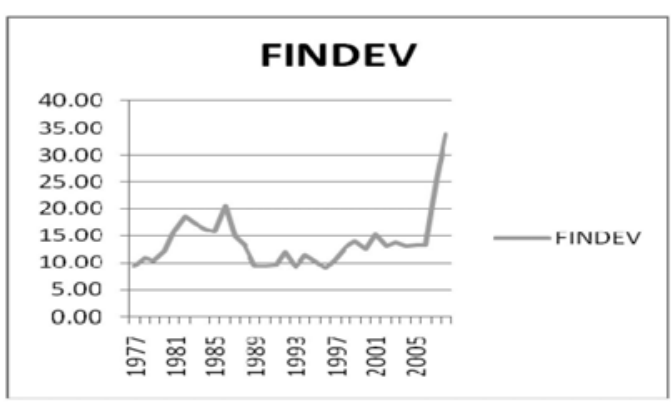

Figure 3. Financial Development (cps/gdp)

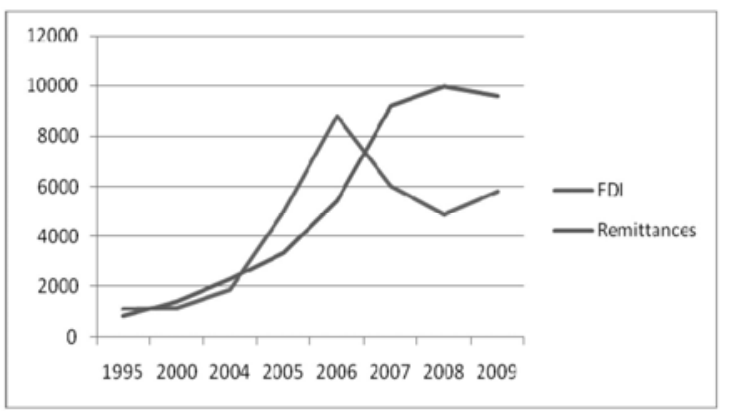

Figure 2. Resource Flows to Nigeria US\$ millions

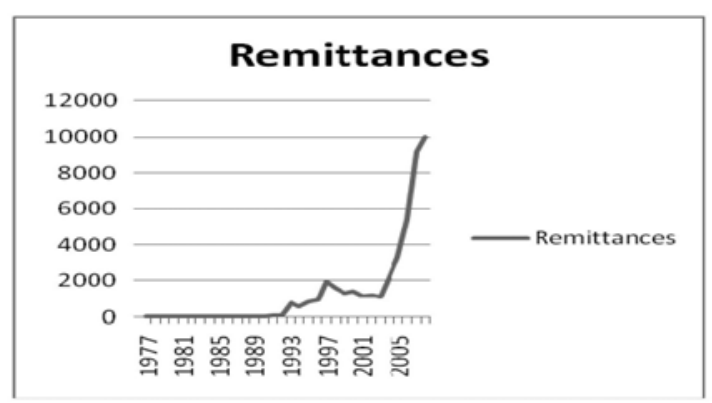

Figure 4. Remittances to Nigeria US\$ millions 